\title{
COPPER, ZINC AND MANGANESE IN SOILS OF TWO WATERSHEDS IN SANTA CATARINA WITH INTENSIVE USE OF PIG SLURRY(1)
}

\author{
Jorge Luis Mattias ${ }^{(2)}$, Carlos Alberto Ceretta ${ }^{(3)}$, Cristiano Nunes \\ Nesi $^{(4)}$, Eduardo Girotto ${ }^{(5)}$, Eder Efrain Trentin ${ }^{(6)}$, Cledimar Rogério \\ Lourenzi $^{(7)}$ \& Renan Costa Beber Vieira ${ }^{(8)}$
}

\begin{abstract}
SUMMARY
Systematic pig slurry application to crop soils may lead to the accumulation of heavy metals in regions with intensive pig raising. The aim of this study was to evaluate the accumulation of $\mathrm{Cu}, \mathrm{Zn}$ and $\mathrm{Mn}$ in soils under systematic pig slurry application. For this purpose, soil samples were collected from two of the most representative watersheds of Santa Catarina where the predominant activity is pig raising. In each watershed, 12 properties were chosen to evaluate the different systems of pig husbandry (complete cycle (CC), farrowing (FaU) and finishing units (FiU)). Based on information of the producers, soil samples were collected in areas with and without systematic manure application. To determine the total $\mathrm{Cu}$, $\mathrm{Zn}$ and Mn content in soils and manure, a methodology proposed by the Environmental Protection Agency of the United States (USEPA), method $\mathbf{n}^{\circ} 3050 \mathrm{~B}$, was used. For the available heavy metal content, $\mathrm{Cu}$ and $\mathrm{Zn}$ was extracted with
\end{abstract}

(1) Part of the doctoral work from the first author developed at the Universidade Federal de Santa Maria (Federal University of Santa Maria). Received for publication in November 2009 and approved in July 2010.

(2) Professor of the Centro de Ciências Agro-Ambientais (Agricultural Environmental Sciences Center) - UNOCHAPECO; Cx postal 747, CEP 89809-000. E-mail: jlmattias@gmail.com

(3) Agronomist, Doctor in Soil Science, Professor of the Soil Department at the Universidade Federal de Santa Maria, Rural Sciences Center - CCR. Caixa Postal 221, CEP 97105-900 Santa Maria (RS), Brazil. Scholarship holder of Productivity in Research from the CNPq. E-mail: carlosceretta@gmail.com

(4) Agronomist, Master in Statistics and Agronomic Experimentation. Epagri/ - Cepaf. Servidão Ferdinando Tusset, s.n., CEP 89801970, Chapecó (SC). E-mail: cristiano@epagri.sc.gov.br

(5) Agronomist, Master in Soil Science, Doctoral Candidate in the Graduate Studies Program in Soil Science at the Universidade Federal de Santa Maria, Rural Sciences Center - CCR. Caixa Postal 221, CEP 97105-900 Santa Maria (RS), Brazil. Doctoral studies scholarship holder from the CNPq. E-mail: eduardogirotto@hotmail.com

(6) Agronomist, with a degree from the Federal University of Santa Maria. E-mail: edertrentin@hotmail.com

(7) Agronomist, Master's degree from the Graduate Studies Program in Soil Science from the Federal University of Santa Maria. Master's degree scholarship holder from CAPES. E-mail: crlourenzi@yahoo.com.br

(8) Agronomist, Master's degree from the Graduate Studies Program in Soil Science from the Federal University of Rio Grande do Sul, School of Agronomy, Soil Dept., Porto Alegre (RS), Brazil. Master's degree scholarship holder from the CNPq. E-mail: renancbvieira@yahoo.com.br 
HCl $0.1 \mathrm{~mol} \mathrm{~L}^{-1}$ and Mn with KCl $1 \mathrm{~mol} \mathrm{~L}^{-1}$. Data were subjected to multivariate analysis, using the canonical discriminant analysis to identify the metals that best differentiate the soils studied within each swine housing system. Successive pig slurry applications cause an increase in $\mathrm{Cu}, \mathrm{Zn}$ and $\mathrm{Mn}$ availability in the soil and this indicates the need for monitoring of the metal concentrations over time. The critical values of $\mathrm{Cu}$ in the soil can be reached and exceeded more rapidly than $\mathrm{Zn}$. The results showed that the soil type may be one of the attribute underlying the determination of public policies in pig raising and waste management because soils such as Inceptisols were shown to be more prone to possible contamination since they may more rapidly reach total critical $\mathrm{Cu}$ levels.

Index terms: heavy metals, animal manure, environmental contamination.

\author{
RESUMO: COBRE, ZINCO E MANGANÊS EM SOLOS DE DUAS \\ MICROBACIAS HIDROGRÁFICAS DE SANTA CATARINA, COM \\ USO INTENSIVO DE DEJETO LÍQUIDO DE SUÍNOS
}

\begin{abstract}
A aplicação sistemática de dejeto líquido de suínos em solos agrícolas pode levar ao acúmulo de metais pesados em regiões com criações intensivas de suínos. O objetivo deste trabalho foi avaliar a acumulação de Cu, Zn e Mn em solos sob aplicação sistemática de dejeto líquido de suínos. Para isso, foram coletadas amostras de solos de duas das mais representativas microbacias hidrográficas de Santa Catarina, onde a atividade predominante é a suinocultura. Em cada microbacia foram escolhidas 12 propriedades que representassem os diferentes sistemas de criação de suínos (unidades de ciclo completo $(C C)$, de produção de leitões $(F a U) e$ de terminação (FiU)). As amostras de solo foram coletadas em áreas definidas pelos produtores como aquelas que receberam aplicação sistemática de dejetos e em áreas que nunca receberam aplicação de dejetos. Para a determinação dos teores totais de Cu, Zn e Mn nos solos e nos dejetos foi utilizada metodologia proposta pela Agência de Proteção Ambiental dos Estados Unidos (USEPA), método $N^{o} 3050 B$, já para os teores disponiveis de metais pesados foi

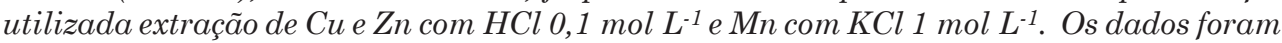
submetidos à análise multivariada, utilizando-se a técnica de análise canônica discriminante para identificar, entre os metais avaliados, aqueles mais relevantes na separação dos solos estudados dentro de cada sistema de criação. Sucessivas aplicações de dejetos líquidos de suinos causam aumento na disponibilidade de $\mathrm{Cu}$, Zn e Mn no solo e isso justifica a necessidade de monitoramento de seus teores ao longo do tempo. $\mathrm{O} C \mathrm{Cu}$, mais rapidamente que o $\mathrm{Zn}$, pode atingir teores totais no solo acima de valores críticos. Os resultados mostraram que o tipo de solo pode ser um dos atributos utilizados na determinação de políticas públicas à criação de suínos e gestão dos dejetos, porque ficou evidenciado que solos como Cambissolos são mais propensos a possíveis contaminações, uma vez que mais rapidamente podem atingir teores totais críticos de $\mathrm{Cu}$.
\end{abstract}

Termos de indexação: metais pesados, dejeto de animais, contaminação ambiental.

\section{INTRODUCTION}

Due to industrialization, mainly in the last 50 years, a large quantity of elements has been dispersed in the environment, especially metals. From this perspective, most environmental problems can be seen as a direct or indirect consequence of pollution arising from human needs, especially generating large amounts of industrial and urban waste resulting from intense use of industrialized products and fossil fuels. Various environmental studies indicate that man has become the most disruptive factor in the biogeochemical cycle of heavy metals (Sodré et al., 2001).
The great majority of studies on heavy metals focus on the application of urban and industrial residues to the soil (Selbach et al., 1999; Ashworth \& Alloway, 2004; McBride \& Cherney, 2004; Ortiz \& Alcañiz, 2006); however, agricultural activities such as pig raising also have a pollution potential in terms of accumulation of some heavy metals in the soil (Scherer $\&$ Nesi, 2004), contributing to soil and environmental contamination, which may have consequences, especially for plants and microorganisms.

In the southern region of Brazil, particularly in Rio Grande do Sul (RS) and Santa Catarina (SC) states, pig raising is an activity developed on small properties where the manure produced is used as fertilizer on 
areas of annual grain crops and pasture. This is an advantageous situation since the nutrients contained in the manure are reused in the production unit itself. However, on many properties, the quantity of manure produced exceeds the soil support capacity. As a consequence, due to the high concentrations of $\mathrm{Cu}$, $\mathrm{Zn}$ and $\mathrm{Mn}$ in the manure (L'Herroux et al., 1997; Jondreville et al., 2003; Mantovi et al., 2003; Gräber et al., 2005; Girotto, 2007), excessive accumulation of these elements in the soil can be expected over the years. Other metals such as $\mathrm{Pb}, \mathrm{Ni}, \mathrm{Cr}$, and $\mathrm{Cd}$ may be found in pig manure since they are present in minerals supplied in commercial feed. In contrast with $\mathrm{Cu}, \mathrm{Zn}$ and $\mathrm{Mn}$, these elements are not essential for crop growth and are generally phytotoxic, even at low concentrations (Moral et al., 2008). In noncontaminated soils, $\mathrm{Cu}$ and $\mathrm{Zn}$ are found in greater quantity connected to organic and inorganic fractions, respectively. They are retained by physical and, mainly, chemical bonds with high degrees of energy. Consequently, the quantity of these heavy metals that are bioavailable and, especially, the concentration in the soil solution are very low. The chemical elements added to the soil by human activity are distributed in pre-existing forms (Rheinheimer et al., 2003), but with lower adsorption energy or in precipitates with greater solubility. Thus, the speciation of heavy metals between the solid phase and the soil solution depends on the quantity added, the quantity and type of adsorbent (organic matter, silicate minerals, manganese and iron oxides and phosphate groups) and the geochemical conditions of the solution, especially the concentration of protons and ionic strength (McBride, 1994).

Thus, intensive pig manure application can raise the levels of heavy metal available in the soil. These changes can be observed by simply determining the total and plant available contents in the soil. Nevertheless, detailed studies are scarce in the swineproducing regions of Santa Catarina which are characterized by high density of animal raising and continuous manure application to the soil. Thus, the objective of the study was to evaluate the $\mathrm{Cu}, \mathrm{Zn}$ and Mn accumulation in soils of two watersheds of Santa Catarina under intensive pig slurry application.

\section{MATERIAL AND METHODS}

The study was developed in two small watersheds (WSH) in the state of Santa Catarina, both characterized by an elevated concentration of pig farms, one in the south of the state in the municipality of Braço do Norte - Coruja/Bonito River Watershed (Microbacia Rio Coruja/Bonito), and the other in the west of the state in the municipality of Concórdia Lajeado Fragosos Watershed. (Microbacia Lajeado Fragosos).
In each watershed 12 properties were chosen to evaluate: (a) different pig raising systems: complete cycle (CC) units, including all phases of pig raising, in other words, farrowing and nursery, weaning and finishing; farrowing unit (FaU), in other words, farrowing and raising of piglets; and finishing unit (FiU), for fattening and finishing of the animals after weaning; (b) establishments located in the three most representative soil classes of each WSH. In Coruja/ Bonito soil samples were taken in Ultisol, Entisol and Inceptisol and in Lajeado Fragosos, samples were taken in Oxisol, Alfisol and Inceptisol (Estados Unidos, 1999).

Based on information of the producers, soil samples were collected in areas defined as systematically application of manure, sampled at a depth of $0.0-$ $0.20 \mathrm{~m}$ with a cutting shovel. In each area, six representative subsamples were collected to compose the sample used in soil analysis. In addition, soil samples were collected in adjacent areas with the same soil class, which had never received manure application. The soil samples were air-dried under systematic turning for rapid drying and standardized moisture. The drying temperature was always kept low so as not to lose residues, nor cause alterations in the oxidation reduction potential of the material, which could lead to losses and/or transformations of elements by alteration of the oxidation state of the existing heavy metals, especially Mn (Abreu et al., 2002). After drying, the clods in the samples were manually broken up with a clod-breaking roller protected with plastic, which was discarded for each sample, sieved through $2.0 \mathrm{~mm}$ plastic mesh and stored. The $\mathrm{pH}$ was determined in water in the proportion 1:1 according to the method proposed by Tedesco et al. (1995) and in soil organic matter (SOM) through wet oxidation with potassium dichromate in a sulfuric acid medium $\left(0.07 \mathrm{~mol} \mathrm{~L}^{-1}\right)$ and determination by titration with ferrous ammonium sulfate $0.1 \mathrm{~mol} \mathrm{~L}^{-1}$ according to Embrapa (1997).

The pig slurry samples, after slurry homogenization, were collected directly from the stored waste (manure piles) on the farms, placed in plastic containers and taken to the laboratory where they were dried at a temperature of $40 \pm 5{ }^{\circ} \mathrm{C}$. Afterwards, the dry samples were manually ground in an agate mortar for analysis.

For determination of the total heavy metal content in the soils and pig slurry, a mixture of hydrogen peroxide $\left(\mathrm{H}_{2} \mathrm{O}_{2}\right)+$ nitric acid $\left(\mathrm{HNO}_{3}\right)+$ hydrochloric acid $(\mathrm{HCl})$ under heating was used, according to the methodology proposed by the Environmental Protection Agency of the United States (USEPA), method no. 3050B (2003). This method is characterized by a strongly acid extraction which allows determination of the metals considered environmentally available. For analysis of the contents considered available to plants, extraction of $\mathrm{Cu}$ and $\mathrm{Zn}$ with $\mathrm{HCl} 0.1 \mathrm{~mol} \mathrm{~L}^{-1}$ and of $\mathrm{Mn}$ with $\mathrm{KCl}$ $1.0 \mathrm{~mol} \mathrm{~L}^{-1}$ was performed according to Tedesco et al.(1995), which is adopted as the standard by the 
Chemical and Soil Fertility Commission of the States of RS and SC (CQFS-RS/SC, 2004). Both the available and total contents were measured using an atomic absorption spectrophotometer, GBC brand, model 932 AA.

The data were subjected to multivariate analysis, using the canonical discriminant analysis technique to identify the most relevant metals in discrimination of the different soils under the three swine production systems in each watershed. However, before analysis, the variables were standardized due to the difference of scale, to adjust the mean to zero and variance to unity. Analysis was also used to separate the soils based on canonical discriminant functions (PimentelGomes, 2000).

The contribution of heavy metal contents in distinction of soils in the different housing systems is given by the values of the standardized canonical coefficient (SCC), of the correlation coefficient (r) and by the parallel discrimination rate (PDR) (Table 4), so that SCC explains the multivariate behavior of the contents in promoting separation of the soils in terms of analysis of the contents of metals individually but considering the other elements, while the correlation coefficient ( $\mathrm{r}$ ) expresses the individual contribution of the heavy metal contents in the soils apart from the rest, and the PDR, which is the product of the SCC by the correlation coefficient (r), also indicates the separation of the soils. Positive values of the SCC indicate the effect of separation among the soils, and negative values of similarities among the soils, and greater values present greater weight in distinction among the soils (Cruz-Castillo et al., 1994).
Thus, the scores obtained from the first canonical discriminant function, considering the six variables (metal content - total and available) were subjected to analysis of variance, taking into account the completely randomized model, comparing the means of the scores of each soil by orthogonal contrasts.

\section{RESULTS AND DISCUSSION}

The $\mathrm{pH}$ of the soils of the WSHs is highly variable, characterizing the soils as acidic and slightly acidic (CQFS-RS/SC, 2004, Table 1). A direct influence of manure application to the soil $\mathrm{pH}$ was not observed, similar to the results of Scherer et al. (1996), Ceretta et al. (2003) and Scherer et al. (2007). Nevertheless, there are results where there was alteration in soil $\mathrm{pH}$, and one example is the study of L'Herroux et al. (1997), who observed an increase in the $\mathrm{pH}$ value, ranging from 5.9-7.0, after four years of pig slurry applications at a rate of approximately $1,000 \mathrm{~m}^{3} \mathrm{ha}^{-1}$ year ${ }^{-1}$. The authors assumed that the alterations occurred due to the high quantity of ions such as $\mathrm{Ca}$, $\mathrm{Mg}$ and $\mathrm{CO}_{3}{ }^{2-}$ present in the manure, different from the manure used in this with low $\mathrm{Ca}$ and $\mathrm{Mg}$ concentrations (Table 2). On the other hand, in the United States, Adeli et al. (2008), studying three soils with different acidities and subjected to applications of pig waste, verified that there was a $\mathrm{pH}$ reduction in the $0-15 \mathrm{~cm}$ soil layer. Nevertheless, $\mathrm{pH}$ reductions were lowest in the soil with alkaline quality due to greater retention of ions in the soil such as $\mathrm{NH}_{4}{ }^{+}$, $\mathrm{Ca}^{2+}$ and $\mathrm{Mg}^{2+}$.

Table 1. Mean values of soil properties in the watersheds and pig production systems evaluated

\begin{tabular}{|c|c|c|c|c|c|c|c|}
\hline Housing System & Type of Soil & $\mathbf{p H}$ & SOM & Clay & Sand & Silt & CTC \\
\hline \multirow{5}{*}{ Complete Cycle } & & \multicolumn{4}{|c|}{$\mathrm{g} \mathrm{kg}^{-1}$ Coruja/Bonito River $\mathrm{g} \mathrm{kg}^{-1}$} & 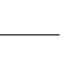 & $\mathrm{cmol}_{\mathrm{c}} \mathrm{kg}^{-1}$ \\
\hline & Ultisol & 5.7 & 18.1 & 240 & 614 & 146 & 6.53 \\
\hline & Inceptisol & 5.0 & 35.0 & 176 & 594 & 229 & 9.19 \\
\hline & Entisol & 6.0 & 23.4 & 337 & 537 & 126 & 7.18 \\
\hline & Ultisol & 5.1 & 36.6 & 280 & 531 & 188 & 10.49 \\
\hline \multirow[t]{2}{*}{ Farrowing } & Inceptisol & 5.1 & 29.1 & 280 & 531 & 188 & 9.59 \\
\hline & Entisol & 4.4 & 24.5 & 299 & 472 & 229 & 4.72 \\
\hline \multirow{3}{*}{ Finishing } & Ultisol & 4.8 & 32.4 & 186 & 416 & 398 & 5.54 \\
\hline & Inceptisol & 5.2 & 31.1 & 217 & 568 & 215 & 8.19 \\
\hline & Entisol & 5.9 & 31.2 & 195 & 540 & 264 & 8.29 \\
\hline \multicolumn{8}{|c|}{ Lajeado Fragosos } \\
\hline & Alfisol & 5.3 & 33.2 & 503 & 230 & 268 & 12.32 \\
\hline & Inceptisol & 5.9 & 33.0 & 683 & 79 & 238 & 16.15 \\
\hline Complete Cycle & Oxisol & 5.2 & 32.0 & 630 & 107 & 263 & 12.06 \\
\hline \multirow{3}{*}{ Farrowing } & Alfisol & 5.4 & 27.5 & 578 & 162 & 260 & 13.79 \\
\hline & Inceptisol & 5.4 & 33.2 & 655 & 121 & 224 & 13.17 \\
\hline & Oxisol & 5.3 & 33.4 & 552 & 151 & 296 & 11.95 \\
\hline \multirow{3}{*}{ Finishing } & Alfisol & 5.6 & 32.3 & 373 & 193 & 434 & 14.82 \\
\hline & Inceptisol & 4.5 & 31.2 & 391 & 261 & 348 & 10.71 \\
\hline & Oxisol & 63 & 370 & 709 & 89 & 202 & 1932 \\
\hline
\end{tabular}

SOM: Soil Organic Matter; CTC: Cation Exchange Capacity. 
Table 2. Mean values of $\mathrm{pH}$ and of $\mathrm{N}, \mathrm{P}, \mathrm{K}, \mathrm{Ca}, \mathrm{Mg}, \mathrm{Cu}, \mathrm{Zn}$, and $\mathrm{Mn}$ contents in the pig slurry applied, of the quantities of pig slurry applied per year and of the time of application in the watersheds and pig production systems evaluated

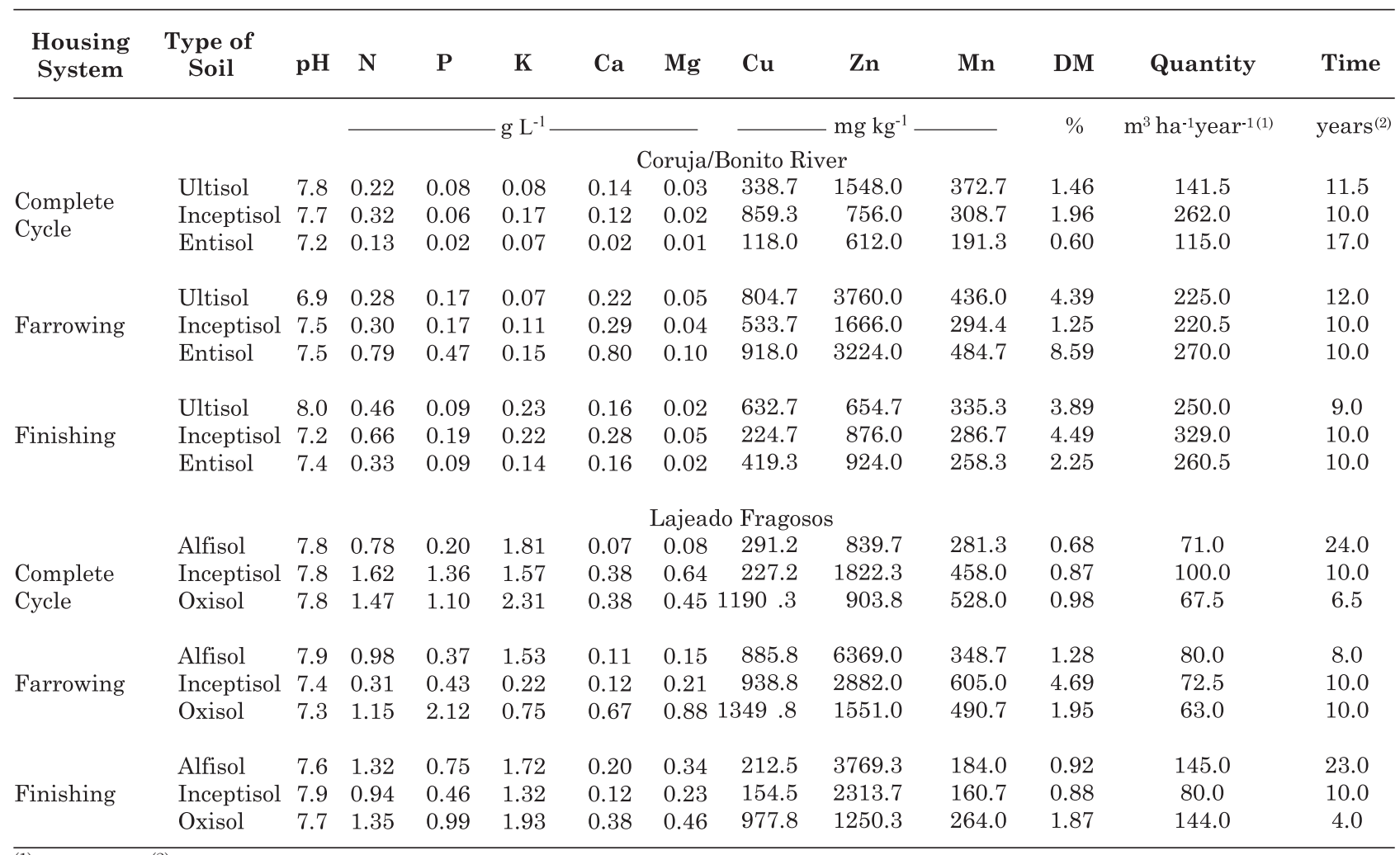

(1) Estimate. ${ }^{(2)}$ Data provided by producers; DM: Dry matter.

At the $\mathrm{pH}(\mathrm{pH}<5.5)$ of most of the soils studied, elements such as $\mathrm{Cu}, \mathrm{Zn}$ and $\mathrm{Mn}$ have greater lability, especially in the disposal areas where pig waste is systematically applied. The reason is that in weathered soils, most charges are $\mathrm{pH}$-dependent and organic matter is responsible for up to $80 \%$ of the soil CTC (Quaggio, 2000). This means that in most of these areas the increase in soil $\mathrm{pH}$ by means of application of soil acidity correctives, with consequent increase in cation exchange capacity (CTC), may result in greater soil retention capacity of these cations, increasing $\mathrm{Cu}, \mathrm{Zn}$ and $\mathrm{Mn}$ adsorption and consequently diminishing their mobility in the environment. Due to its relevance, the influence of $\mathrm{pH}$ on heavy metal availability was the object of investigation by other authors, such as Pombo \& Klamt (1986), and is considered one of the main properties that regulate the adsorption of heavy metals in soils besides CTC, organic matter content, content and clay mineral type and amorphous oxide content (McBride, 1989).

The CTC of the study soils is medium, according to the CQFS-RS/SC (2004). This soil property appears to have less influence on the soil metal contents than the quantities added systematically. When there are elevated additions in the soils with the mean CTC, as in the case of the FaU's in Entisols of the Coruja/ Bonito River WSH, the metal contents present in the soils are more evident (Tables 1 and 3).

The organic matter contents in the soil were classified as medium (CQFS-RS/SC, 2004) in most cases, despite the different soils properties influencing the maintenance of soil organic matter. Higher clay contents may have led to greater organic matter contents in the soils of the Fragosos WSH than the Coruja/Bonito River WSH due to the greater physical protection of soil organic matter against mineralization. This similarity in the soil organic matter contents possibly arises from the traditional soil type management used in the two WSHs. In Coruja/Bonito, the land was used for pasture for dairy production and in Fragosos, the areas were predominantly used to grow corn for feed production, with soil tilling, until very recently. Besides, in the areas with direct animal grazing, most of the plant matter produced is transferred by the animals which explains the lack of alteration in the soil organic matter content, as suggested by Ceretta et al. (2003).

There was no evidence of the influence of date and quantity of manure application on the soil organic matter content, as similarly observed by Ceretta et 
Table 3. Total and available mean contents of $\mathrm{Cu}, \mathrm{Zn}$ and $\mathrm{Mn}$, followed by the canonical discriminant function 1 involving these six variables in each pig production system, soil type and watershed

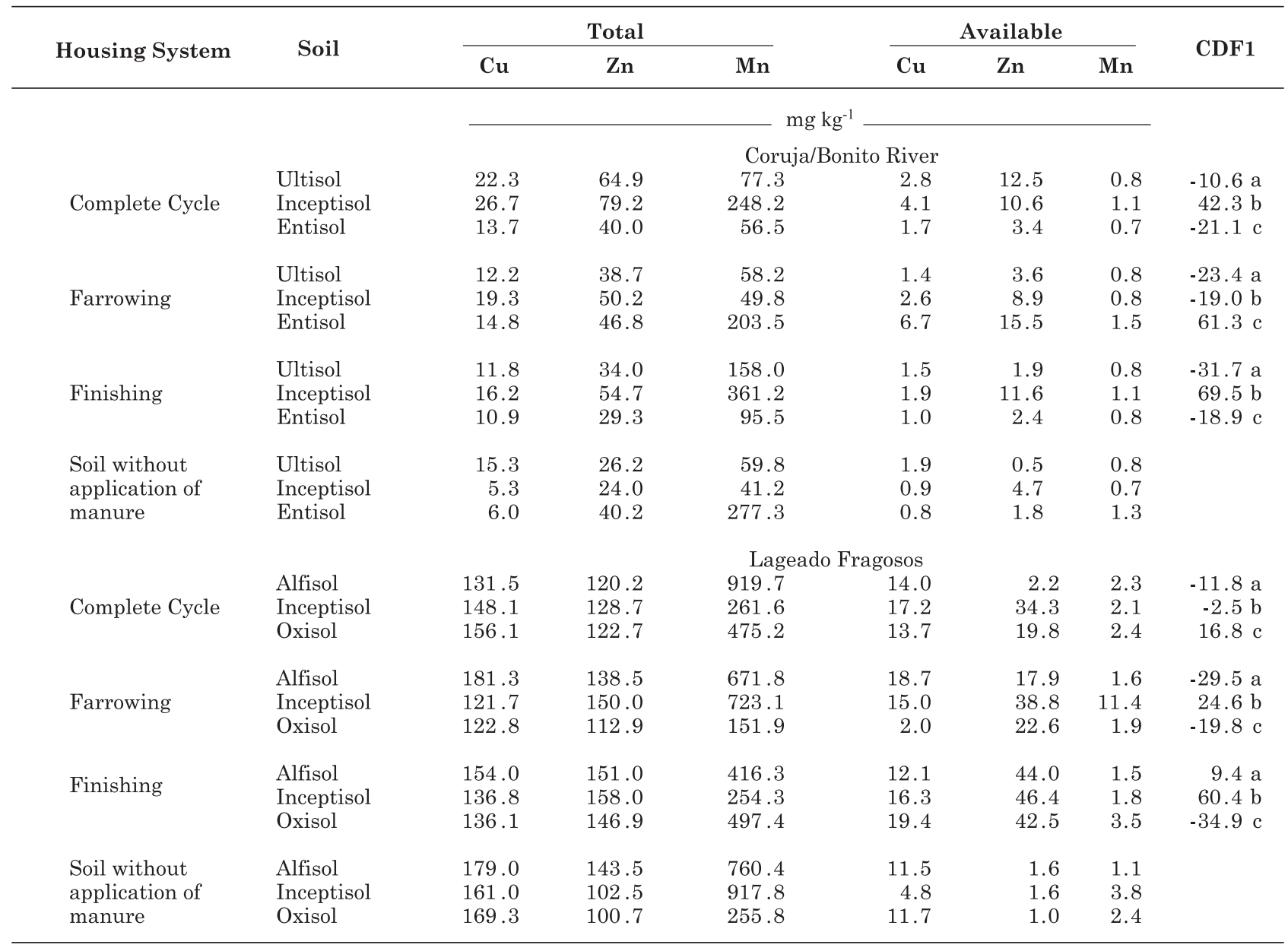

CDF1: Canonical discriminant function 1.

al. (2003). These authors evaluated the properties of soil treated with 28 pig slurry applications in a four year period in an area from which most of the plant matter produced was removed to feed cattle. Similalry, Ellerbrock et al. (1999) observed no alteration in the total soil $\mathrm{C}$ content in a 34 year application period. This behavior may be explained by the low dry matter content of manure or by the proper characteristics of the carbon-containing compounds of pig slurry, which, for being rich in polysaccharides, protein, lipids and other compounds (Dinel \& Gregorich, 1995), are considered easily degradable. Thus, manure application does not lead to an accumulation of soil organic matter, indicating that in areas used for waste disposal, the organic matter content will only increase when soil conservation practices are adopted to promote accumulation of organic matter.

The quantities of $\mathrm{Cu}, \mathrm{Zn}$ and $\mathrm{Mn}$ applied to the soil through pig manure in the Coruja/Bonito River WSH were greater than those in Lajeado Fragosos (Table 2). This may be explained by the different application types used in the WSHs. While in Lajeado
Fragosos manure is applied with distributors connected to tractors, most distribution in the Coruja/ Bonito WSH is performed through pasture fertigation systems with pig slurry, which facilitates more frequent applications at higher doses.

The Wilks' Lambda multivariate statistical test showed significant differences among the soils in the different housing systems studied $(\mathrm{p}<0.05)$ with regard to the canonical discriminant function 1 (CDF1) (Table 4).

Analyzing the SCC values of the total heavy metal content in the soils of Coruja/Bonito in the CC system, it can be observed that total Mn contributed most to distinguish the soils (18.01), accounting for approximately $99 \%$ of the difference. This is shown by the greater PDR (Table 4). In the FaU system, the element with clearest distinction of the soils was available $\mathrm{Cu}$ (33.33) accounting for $89 \%$ of the distinction and PDR of 29.66. In the FiU system, available $\mathrm{Zn}$ contributed to the distinction among the soils with $98 \%$ and PDR of 46.31 . 
Table 4. Standardized canonical coefficient (SCC), linear correlation coefficient (r) and parallel discrimination rate (PDR) with regard to the canonical discriminant function 1 (CDF1) for the total and available mean $\mathrm{Cu}, \mathrm{Zn}$ and $\mathrm{Mn}$ contents

\begin{tabular}{|c|c|c|c|c|c|c|c|}
\hline \multirow{2}{*}{ Housing System } & \multirow{2}{*}{ Soil } & \multicolumn{3}{|c|}{ Total } & \multicolumn{3}{|c|}{ Available } \\
\hline & & $\mathrm{Cu}$ & $\mathrm{Zn}$ & Mn & $\mathrm{Cu}$ & $\mathrm{Zn}$ & Mn \\
\hline $\begin{array}{l}\text { Complete } \\
\text { Cycle }\end{array}$ & $\begin{array}{l}\mathrm{CCP} \\
\mathrm{r} \\
\mathrm{TDP}\end{array}$ & $\begin{array}{r}-8.13 \\
0.44 \\
-3.58\end{array}$ & $\begin{array}{l}9.63 \\
0.62 \\
5.97\end{array}$ & $\begin{array}{r}\text { a/Bonito } \\
18.01 \\
0.99 \\
17.83\end{array}$ & $\begin{array}{l}4.07 \\
0.60 \\
2.44\end{array}$ & $\begin{array}{r}-3.50 \\
0.16 \\
-0.56\end{array}$ & $\begin{array}{l}4.01 \\
0.94 \\
3.77\end{array}$ \\
\hline Farrowing & $\begin{array}{l}\mathrm{CCP} \\
\mathrm{r} \\
\mathrm{TDP}\end{array}$ & $\begin{array}{r}-4.41 \\
-0.13 \\
0.57\end{array}$ & $\begin{array}{r}13.11 \\
0.03 \\
-0.39\end{array}$ & $\begin{array}{l}6.63 \\
0.97 \\
6.43\end{array}$ & $\begin{array}{r}33.33 \\
0.89 \\
29.66\end{array}$ & $\begin{array}{l}1.79 \\
0.65 \\
1.16\end{array}$ & $\begin{array}{r}-0.38 \\
0.98 \\
-0.37\end{array}$ \\
\hline Finishing & $\begin{array}{l}\mathrm{CCP} \\
\mathrm{r} \\
\mathrm{TDP}\end{array}$ & $\begin{array}{l}0.98 \\
0.85 \\
0.83\end{array}$ & $\begin{array}{l}6.07 \\
0.89 \\
5.40\end{array}$ & $\begin{array}{l}1.77 \\
0.91 \\
1.61\end{array}$ & $\begin{array}{r}12.08 \\
0.69 \\
-8.34\end{array}$ & $\begin{array}{r}47.25 \\
0.98 \\
46.31\end{array}$ & $\begin{array}{r}-6.10 \\
0.60 \\
-3.66\end{array}$ \\
\hline $\begin{array}{l}\text { Complete } \\
\text { Cycle }\end{array}$ & $\begin{array}{l}\mathrm{CCP} \\
\mathrm{r} \\
\mathrm{TDP}\end{array}$ & $\begin{array}{r}-0.65 \\
-0.60 \\
0.39\end{array}$ & $\begin{array}{r}0.92 \\
-0.16 \\
-0.15\end{array}$ & $\begin{array}{r}\text { ado Fra } \\
8.34 \\
0.97 \\
8.09\end{array}$ & $\begin{array}{r}0.48 \\
-0.39 \\
-0.19\end{array}$ & $\begin{array}{r}-4.21 \\
-0.65 \\
2.74\end{array}$ & $\begin{array}{l}0.46 \\
0.13 \\
0.06\end{array}$ \\
\hline Farrowing & $\begin{array}{l}\mathrm{CCP} \\
\mathrm{r} \\
\mathrm{TDP}\end{array}$ & $\begin{array}{r}-5.86 \\
-0.66 \\
3.87\end{array}$ & $\begin{array}{l}4.57 \\
0.61 \\
2.79\end{array}$ & $\begin{array}{l}2.19 \\
0.44 \\
0.96\end{array}$ & $\begin{array}{r}-0.81 \\
0.23 \\
-0.19\end{array}$ & $\begin{array}{r}14.68 \\
0.74 \\
10.86\end{array}$ & $\begin{array}{r}13.65 \\
0.56 \\
7.64\end{array}$ \\
\hline Finishing & $\begin{array}{l}\mathrm{CCP} \\
\mathrm{r} \\
\mathrm{TDP}\end{array}$ & $\begin{array}{l}11.64 \\
-0.55 \\
-6.40\end{array}$ & $\begin{array}{r}28.89 \\
-0.03 \\
0.57\end{array}$ & $\begin{array}{r}-16.54 \\
0.09 \\
-1.49\end{array}$ & $\begin{array}{r}75.68 \\
0.54 \\
40.87\end{array}$ & $\begin{array}{r}-28.72 \\
-0.03 \\
0.86\end{array}$ & $\begin{array}{l}6.82 \\
0.91 \\
6.21\end{array}$ \\
\hline
\end{tabular}

r: linear correlation coefficient between the canonical discriminant function 1 and each one of the properties evaluated.

In the Lajeado Fragosos WSH the contribution of heavy metals to distinguish the soils as related to the housing systems is also differentiated. For the CC, the factor of differentiation was total Mn, with the greatest SCC (8.34), accounting for $97 \%$ of the difference between the soils and with PDR of 8.09. In the FaUs, the available Zn presented the greatest SCC (14.68), with $74 \%$ responsibility in distinction of the soils and PDR of 10.86, while in the FiUs, the available $\mathrm{Cu}$ was the element of greatest effect on soil distinction with greatest TCP (75.68) and accounting for $54 \%$ of the difference and PDR of 40.87.

Figure 1 shows the standardized canonical coefficients (SCC) of the canonical discriminant functions 1 and 2 (CDF1 and CDF2) for the metal contents in the soils under manure application in the different systems. The combined analysis of the heavy metal contents in the soils was sensitive enough to distinguish the soils under all pig housing systems, indicating the soils most prone to possible contamination.

The heavy metal contents in the soils under pig slurry application were highly variable (Table 3), more associated, mostly, with the quantities applied and the manure metal content than with the soil properties (Table 2). In the Coruja/Bonito River WSH, the soil tending most to environmental contamination is the Inceptisol that always contained highest heavy metal contents in different forms arising from the pig slurry application, with the exception of the available contents in the Entisol of the FaUs. However, the values of total $\mathrm{Cu}$ in the Inceptisol can be up to 5.0 times higher than those found in the soils without slurry application, while total $\mathrm{Zn}$ may be 3.3 times and total Mn up to 8.8 times greater than in the soil without slurry.

The risk of environmental contamination with available $\mathrm{Cu}$ and $\mathrm{Zn}$ is greater in the Entisol coupled with the FaU system, in which most heavy metals are disposed on the environment (Table 2). Besides, the $\mathrm{pH}$ values and organic matter content, which are two of the factors that contribute greatly to the retention of these heavy metals in the soil solid phase, are also the lowest the Entisol in this housing system.

In the case of the Lajeado Fragosos WSH, the situation is quite different. In some situations the total metal contents in the soils without pig slurry application were even greater than in soils that were slurry-treated for a long time. A similar situation was observed by Basso et. al (2002) who analyzed areas with and without systematic pig slurry applications, and identified situations where the contents in soils without applications were similar or even greater contents than in slurry-treated soils. This may be mainly due to the fact that basalt is a material of origin of the soils (Santa Catarina, 1986). This rock is rich in ferromagnesian minerals, which in the process of weathering give rise to various clay 

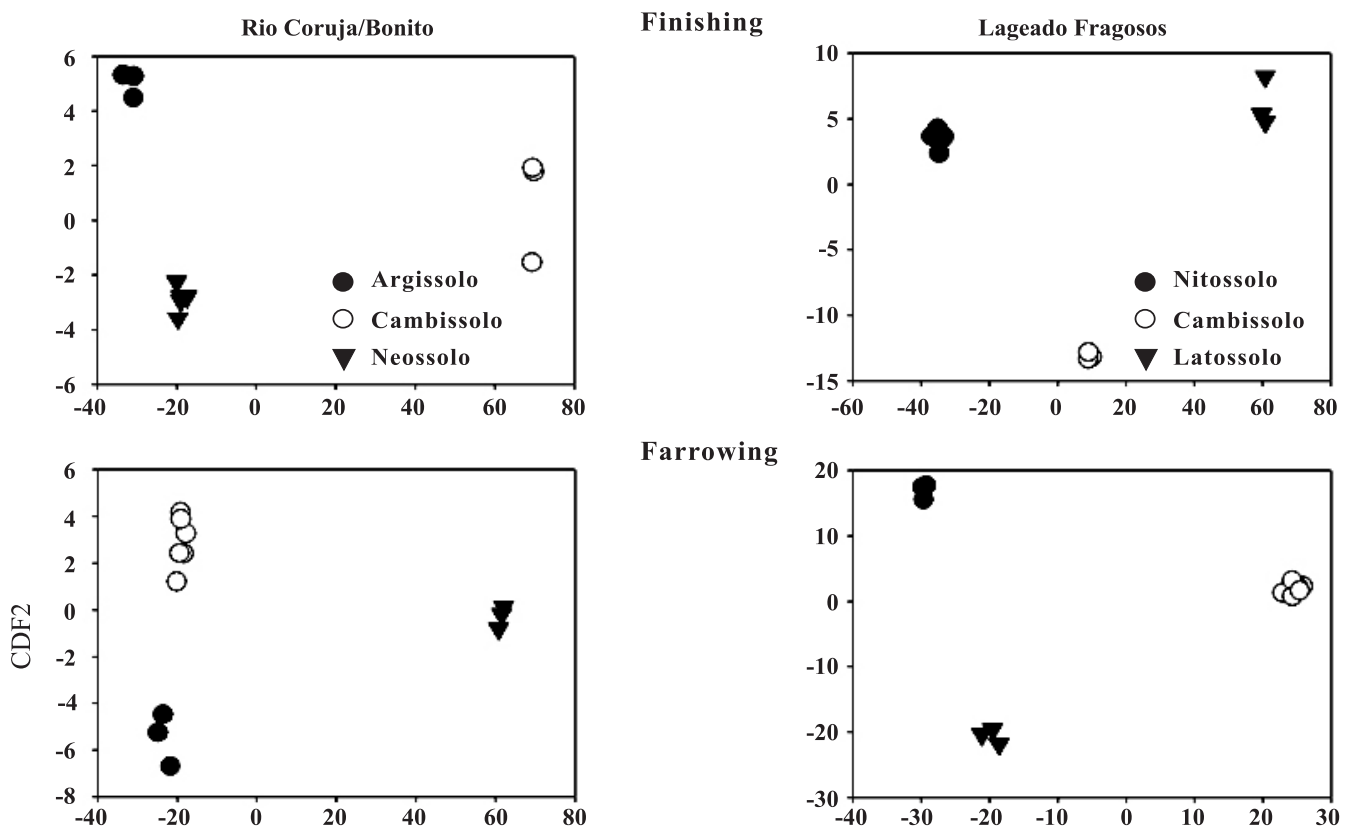

Farrowing
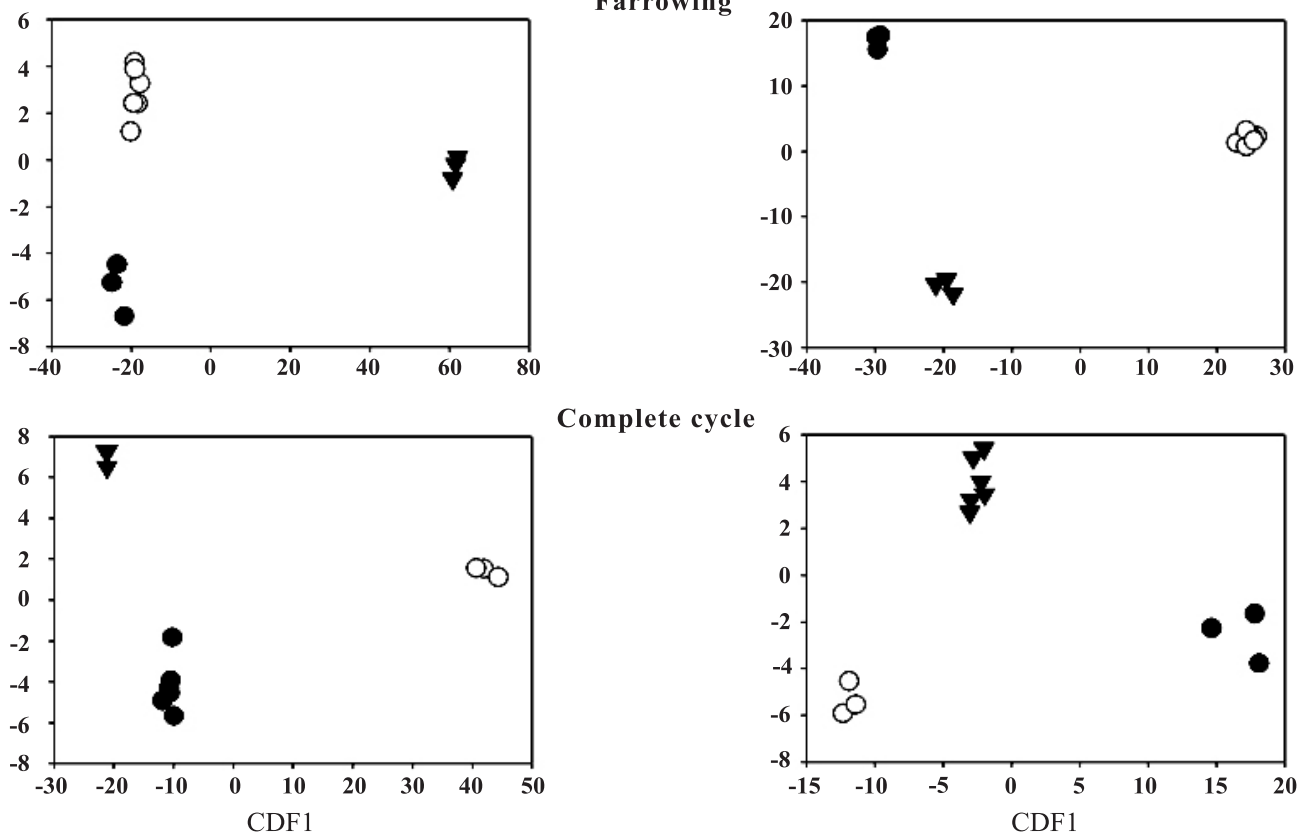

Complete cycle

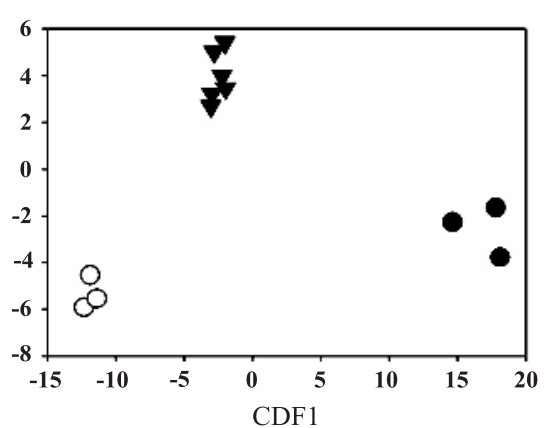

Figure 1. Standardized canonical coefficients of the canonical discriminant functions (CDF) 1 and 2 in three soil types, according to the location and pig production system, considering the total and available heavy metals $\mathrm{Cu}, \mathrm{Zn}$ and $\mathrm{Mn}$.

minerals and metal-rich oxides. In addition, the regional topography is strongly hilly and the period of settlement long, characterized by intense soil removal through conventional preparation, which may have caused heavy metal loss by erosion in the cultivated areas.

In soils similar to those of the Lajeado Fragosos WSH, Scherer \& Nesi (2004) observed Cu accumulation at a depth of $50 \mathrm{~cm}$ (deeper than in the present study) in areas under pig manure application, and attributed this movement to complexation by soluble organic molecules. L'Herroux et al. (1997) also observed heavy metal movement in the soil profile which they ascribed to saturation of the functional groups that most acquire metals in the soil solid fraction of the surface layers, which would increase the fraction of metals available in the soil solution and be subject to percolation. These two effects are possible in the areas of manure application.

The total $\mathrm{Cu}$ and $\mathrm{Zn}$ contents in the different soil classes sampled in the Coruja/Bonito River and
Lajeado Fragosos WSHs (Table 3) are below the socalled investigation value contents of 200 and $450 \mathrm{mg} \mathrm{kg}^{-1}$ soil, respectively (CONAMA, 2009). This investigation value is the concentration of a determined substance in the soil above which there are potential direct or indirect risks to human health under standardized exposure (CONAMA, 2009). Thus, although the sampled soils had been manured for up to 24 years to (Alfisol of the Lajeado Fragosos WSH), no environmental problems were observed so far, according to the CONAMA resolution for agricultural soils.

The use of only the reference soil contents of $\mathrm{Cu}$ and $\mathrm{Zn}$ according to the CONAMA guidelines (CONAMA, 2009), without taking the environment of application into consideration, does not ensure an adequate use of pig manure in the long term. To monitor the environment adequately, principally of the soil, the establishment of critical contents in the different soils and crop systems is necessary, considering the balance of metals in the soil and their 
interrelations with organic and mineral fractions. The reason is that the metal behavior may be influenced by properties of the soil solid phase such as type of adsorbent (organic matter, silicate minerals, manganese and iron oxides and phosphate groups) and the geochemical conditions of the solution, particularly proton concentration and ionic strength (McBride, 1994; Alloway, 1995). Thus, although the total contents of these elements are lower in the soils of the Coruja/Bonito River WSH, one must be more careful with excessive waste applications in this WSH due to the lower clay contents than in the Lajeado Fragosos WSH.

Elevated contents of $\mathrm{Cu}$ and $\mathrm{Zn}$ were observed in the soil available form, up to 3.6 times higher in the case of Inceptisols and 42 times higher in the case of Oxisols of the Lajeado Fragosos WSH. Particularly in this WSH, the probability of environmental contamination seems to be greatest for $\mathrm{Zn}$, since the magnitude of the available form is much higher than of the original contents. This may also be associated with the Zn concentrations in the pig slurry of the different housing systems, which were always greater than of $\mathrm{Cu}$ and $\mathrm{Mn}$, with the exception of the Oxisol in the CC in the Lajeado Fragosos WSH, where the $\mathrm{Cu}$ concentration in the manure was highest (Table 2). Especially in the Farrowing Unit - FaU, Zn contents in the manure are highest, which had been expected, since it is added to the feed in order to reduce the risks of diarrhea when the animals are still in the suckling phase. It may also be observed that in both WSHs, the manure dry matter contents were greatest in the FaU, leading to an increase in the quantity of metals applied in this system (Table 2).

The available $\mathrm{Cu}$ and $\mathrm{Zn}$ contents (extracted with $\mathrm{HCl} 0.1 \mathrm{~mol} \mathrm{~L}^{-1}$ ) found in the soils of the two WSHs (Coruja/Bonito River and Lajeado Fragosos) are classified as "high" (CQFS-RS/SC, 2004). However, this is only a parameter of availability, an indication of the increase in availability due to the application of manure in the soil rather than of possible toxicity of the element to plants or soil microorganisms.

\section{CONCLUSIONS}

1. Successive pig slurry applications increase $\mathrm{Cu}$, $\mathrm{Zn}$ and $\mathrm{Mn}$ availability in the soil, requiring monitoring of their contents over time.

2. Copper may reach total soil contents above critical values more rapidly than $\mathrm{Zn}$.

3. It was shown that soils such as Inceptisols are more prone to possible contaminations, since they may more rapidly reach total critical $\mathrm{Cu}$ contents. This indicates that soil type could be a attribute underlying the determination of public policies regarding pig raising and waste management.

\section{LITERATURE CITED}

ABREU, C.A.; ABREU, M.F. \& BERTON, R.S. Análise química de solo para metais pesados. In: CURI, N.; MARQUES, J.J.; GUILHERME, L.R.G.; LIMA, J.M.; LOPES, A.S.S. \& ALVAREZ V., V.H., eds. Tópicos em ciência do solo. Viçosa, MG, Sociedade Brasileira de Ciência do Solo, 2002. v.2. p.645-692.

ADELI, A.; BOLSTER, C.H.; ROWE, D.E.; McLAUGHLIN, M.R. \& BRINK, G.E. Effect of long-term swine effluent application on selected soil properties. Soil Sci., 173:223235, 2008.

ALLOWAY, B.J. Heavy metals in soils. 2.ed. Glasgow, Blackie Academic \& Professional, 1995. 368p.

ASHWORTH, D.J. \& ALLOWAY, B.J. Soil mobility of sewage sludge-derived dissolved organic matter, copper, nickel and zinc. Environ. Pollut., 127:137-144, 2004.

BASSO, C.J.; CERETTA, C.A.; MOREIRA, I.C.L.; FLORES, E.M.M. \& DRESSLER, V.L. Acúmulo de alguns metais pesados em solos com sucessivas aplicações de esterco líquido de suínos. In: FERTBIO, Rio de Janeiro, 2002. Anais... Rio de Janeiro, 2002. CD ROM.

CERETTA, C.A.; DURIGON, R.; BASSO, CJ.; BARCELLOS, L.A.R. \& VIEIRA, F.C.B. Características químicas de solo sob aplicação de esterco líquido de suínos em pastagem natural. Pesq. Agropec. Bras., 38:729-735, 2003.

COMISSÃO DE QUÍMICA E FERTILIDADE DO SOLO CQFRS/SC. Manual de adubação e calagem para os Estados do Rio Grande do Sul e de Santa Catarina. 10.ed. Porto Alegre, SBCS - Núcleo Regional Sul/UFRGS, 2004. 400p.

CONSELHO NACIONAL DO MEIO AMBIENTE - CONAMA. Resolução no 420, de 28 de dezembro de 2009. Available at: < ht t p ://www.mma.gov.br/port/conama/ legiabre.cfm?codlegi $=620>$. Accessed on: January 20, 2010.

CRUZ-CASTILLO, J.G.; GANESHANANDAM, S.; MACKAY B.R.; LAWES, G.S.; LAWOKO, C.R.O.O. \& WOOLLEY, D.J. Applications of canonical discriminant analysis in horticultural research. Hortic. Sci., 29:1115-1119, 1994.

DINEL, H. \& GREGORICH, E.G. Structural stability status as affected by long-term continuous maize and bluegrass sod treatments. Biol. Agric. Hortic., 12:237-252, 1995.

ELLERBROCK R.H.; HÖHN A. \& ROGASIC J. Functional analysis of soil organic matter as affected by long-term manurial treatment. Europ. J. Soil Sci., 50:65-71, 1999.

EMPRESA BRASILEIRA DE PESQUISA AGROPECUÁRIA EMBRAPA. Centro Nacional e Pesquisa em Solos. Sistema brasileiro de classificação de solos. Brasília, Embrapa-SPI; Rio de Janeiro, Embrapa-Solos, 2006. 306p.

EMPRESA BRASILEIRA DE PESQUISA AGROPECUÁRIA EMBRAPA. Manual de métodos de análises de solo. 2.ed. Rio de Janeiro, Ministério da Agricultura e do Abastecimento, 1997. 212p.

EPA. SW-846 EPA. Acid digestion of sediments, sludges, and soils, method 3050b. Available at: <http://www.epa.gov/ SW-846/pdfs/3050b.pdf $>$ Accessed on: March 1, 2003. 
GIROTTO, G. Cobre e zinco no solo sob uso intensivo de dejeto líquido de suínos. Santa Maria, Universidade Federal de Santa Maria, 2007. 121p. (Tese de Mestrado)

GRÄBER, I.; HANSEN, J.F.; OLESEN, S.E.; PETERSEN, J.; ØSTERGAARD, H.S. \& KROGH, L. Accumulation of copper and zinc in Danish agricultural soils in intensive pig production areas. Danish J. Geogr., 105:15-22, 2005.

JONDREVILLE, C.; REVY, P.S. \& DOURMAD, J.Y. Dietary means to better control the environmental impact of copper and zinc by pigs from weaning to slaughter. Livestock Produc. Sci., 84:147-156, 2003.

L'HERROUX, L.; Le ROUX, L.; APPROU, P. \& MARTINEZ, J. Behaviour of metals following intensive pig slurry applications to a natural field treatment process in Brittany (France). Environ. Pollut., 97:119-130, 1997.

MANTOVI, P.; BONAZZI, G.; MAESTRI, E. \& MARMIROLI, $\mathrm{N}$. Accumulation of copper and zinc from liquid manure in agricultural soils and crop plants. Plant Soil, 250:249$257,2003$.

McBRIDE, M.B. Environmental chemistry of soils. New York, Oxford University, 1994. 406p.

McBRIDE, M.B. Reactions controlling heavy metal solubility in soils. Adv. Soil Sci., 10:1-56, 1989.

McBRIDE, M.B. \& CHERNEY, J. Molybdenum, sulfur and other trace elements in farm soils and forages after sewage sludge application. Comm. Soil Sci. Plant Anal., 35:517-535, 2004.

MORAL, R.; PEREZ-MURCIA, M.D.; PEREZ-ESPINOSA, A.; MORENO-CASELLES, J.; PAREDES, C. \& RUFETE, B. Salinity, organic content, micronutrients and heavy metals in pig slurries from South-eastern Spain. Waste Manag., 28:367-371, 2008.

ORTIZ, O. \& ALCAÑIZ, J.M. Bioaccumulation of heavy metals in Dactylis glomerata L. growing in a calcareous soil amended with sewage sludge. Biores. Technol., 97:545$552,2006$.

PIMENTEL GOMES, F. Curso de estatística experimental. 14.ed. Piracicaba, Degaspari, 2000. 477p.
POMBO, L.C.A. \& KLAMT, E. Adsorção de zinco e cobre de dois solos do estado do Rio Grande do Sul. R. Bras. Ci. Solo, 10:191-194, 1986.

QUAGGIO, J.A. Acidez e calagem em solos tropicais. Campinas, Instituto Agronômico de Campinas, 2000. $111 \mathrm{p}$.

RHEINHEIMER, D.S.; CONTE, E. \& ANGHINONI, I. Formas de acumulação de fósforo pela aplicação de fosfato em solo no sistema plantio direto. R. Bras. Ci. Solo, 27:893900, 2003

SANTA CATARINA. Gabinete de Planejamento e Coordenacão Geral. Atlas de Santa Catarina. Florianópolis, Aerofoto Cruzeiro, 1986. 173p.

SCHERER, E.E. \& NESI, C.N. Alterações nas propriedades químicas dos solos em áreas intensivamente adubadas com dejetos suínos. In: FERTBIO 2004. Anais... Lages, UDESC, 2004. CD ROM

SCHERER, E.E.; AITA, C. \& BALDISSERA, I.T. Avaliação da qualidade do esterco líquido de suínos da região Oeste Catarinense para fins de utilização como fertilizante. Florianópolis, EPAGRI, 1996. 46p. (Boletim Técnico).

SCHERER, E.E.; BALDISSERA, I.T. \& NESI, C.N. Propriedades químicas de um Latossolo Vermelho sob plantio direto e adubação com esterco de suínos. R. Bras. Ci. Solo, 31:123-131, 2007.

SELBACH, P.A.; TEDESCO, M.J.; GIANELLO, C. \& CAMARGO, F.A. O Resíduos urbanos e industriais e a qualidade do ambiente. In: ENCONTRO BRASILEIRO DE SUBSTÂNCIA HÚMICAS, 3., Santa Maria, 1999. Resumos... Santa Maria, 1999. 383p.

SODRÉ, F.F.; LENZI, E. \& COSTA, A.C.S. Utilização de modelos físico-químicos de adsorção no estudo do comportamento do cobre em solos argilosos. Química Nova, 24:324-330, 2001.

TEDESCO, M.J.; GIANELLO, C.; BISSANI, C.A.; BOHNEN, H. \& VOLKWEISS, S.J. Análise de solo, plantas e outros materiais. Porto Alegre, Universidade Federal do Rio Grande do Sul, 1995. 172p. 